\title{
Would 100 Global Workshops on Theory Building Make A Difference?
}

\author{
Knud Erik Jørgensen \\ Aarhus University and Yasar University
}

\begin{abstract}
The paper rests on the assumption that theoretical knowledge is valuable. However, such an assumption cannot be taken for granted. Indeed the first objective is to examine the comparative advantages of theoretical knowledge. Second, if 100 theory building workshops would make a difference, what exactly would the difference be? After all, movie production is said to be dominated by Hollywood but Bollywood produces more movies than Hollywood. Nonetheless, the world market is dominated by Hollywood. Hence, if a distinction between academic domestic and global markets is applied, theory building for a number of domestic or regional markets might impact 'consumption' patterns in domestic or regional markets but not necessarily the world market. Moreover, the apparent need for 100 workshops rests on the assumption that the IR discipline is under American hegemony but this assumption is severely challenged by empirical research showing that American hegemony remains a fact in institutional terms but not in terms of theoretical fads and debates being followed in the rest of the world. In short, intellectual global hegemony is largely a chimera. Finally, the paper argues that 100 workshops might be necessary but could turn out to be waste of time and for two reasons. While theorizing a bygone world is fine, the workshops should address contemporary issues and be future-oriented. Furthermore, the workshops should contribute to redefine the (contested) core of the discipline.
\end{abstract}

Keywords: Theory, theory building, hegemony, markets, discipline, orthodoxy

\section{Would 100 Global Workshops on Theory Building Make a Difference?}

This article is essentially a concrete proposal to convene 100 workshops/panels during the next few years so that the 2019 commemorations of the highly symbolical 1919-2019 centenary can produce not only retrospective but also future-oriented studies. In order to have a lasting impact the workshops should exclusively be for scholars who have an interest in building theory. The guiding idea for the paper is that policies - for instance a policy on globalizing the discipline's theory production - without organizational and public philosophical footings have less potential impact than policies that enjoy such underpinnings. In this sense, Marx' $11^{\text {th }}$ Feuerbach thesis - philosophers have so far only interpreted the world, the point is to change it - remains valid and relevant also for academic practices. While the suggested workshops count as organizational footings, the public philosophical dimension is constituted by the idea that the IR discipline would become more consolidated and globally more relevant if global theorizing were to happen in a fashion that reflect more

Knud Erik Jørgensen, Professor, Department of Political Science, Aarhus University. Email: kej@ps.au.dk. 
diverse origins. Four observations make me think that the conditions for such an enterprise do exist. We are - cf. the 2013 special issue of the EJIR - in an 'end of IR theory' situation; Theorizing in one of the main centres of the discipline, the United States, does experience significant decline; ${ }^{1}$ Theorizing in Europe is more dispersed than concerted and hegemonic; New centres of knowledge production are being established with potentials for consolidating both the discipline and its theories. In short, the timing for such an 100 workshops enterprise seems perfect.

The paper is structured in five parts. While the paper rests on the assumption that theoretical knowledge is valuable such an assumption cannot be taken for granted. The first section therefore examines the assumption and outlines the comparative advantages of theoretical knowledge. The second section provides a brief market analysis. If 100 workshops would make a difference, what exactly would the difference be? After all, movie production is said to be dominated by Hollywood but Bollywood produces more movies than Hollywood. Nonetheless, the world market is dominated by Hollywood. Hence, if Jean Leca's distinction between academic domestic and global markets is applied, ${ }^{2}$ theory building for a number of domestic or regional markets might impact 'consumption' patterns in domestic or regional markets but not necessarily the world market. The third section raises some serious doubts about the widespread belief that the discipline is characterized by American hegemony. The apparent need for 100 workshops could be legitimized by the argument that the IR discipline is under American hegemony but this assumption is severely challenged by empirical research showing that American hegemony is a fact in institutional terms but not in terms of theoretical fads and debates being followed in the rest of the world. In short, intellectual global hegemony is a chimera, a largely imagined state of affairs for which reason the rationale of the workshops cannot be anti-hegemonic. In the fourth section, the paper argues that 100 workshops might be necessary but would essentially be waste of time if focused on theorizing a bygone world. In the fifth and final section the paper makes the argument that the 100 workshops should contribute to redefine what is perceived to be the core of the discipline, i.e. what Ted Hopf calls 'a particular well-known consensually foundational literature'. ${ }^{3}$ It is only if analysts begin by ignoring non-American, non-European or non-Western conceptions of foundational literature that they subsequently can construct a hegemonic global state of affairs and, in turn criticize what they have constructed.

John J. Mearsheimer and Stephen M. Walt, "Leaving Theory Behind: Why Simplistic Hypothesis Testing Is Bad For International Relations," European Journal of International Relations 19, no. 3 (2013): 427-57.

Jean Leca, "La science politique dans le champ intellectuel français," Revue française de science politique 4 (1982): 653-77.

Ted Hopf, Social Construction of International Politics: Identities and Foreign Policies, Moscow, 1955 and 1999 (Ithaca: Cornell University Press, 2002). The paper draws on, synthesizes, summarizes and adds to my previous publications. In "Continental IR Theory: The Best Kept Secret" (Knud Erik Jorgensen, "Continental IR Theory: The Best Kept Secret," European Journal of International Relations 6, no. 1 (2000): 9-42) I intended to provoke Anglo-Saxon minds to the idea that the (European) Continental IR community produces IR theory of some significance. In "Towards a Six Continents Social Science: International Relations" (Knud Erik Jorgensen, "Towards a Six Continents Social Science: International Relations," Journal of International Relations and Development 6, no. 4 (2004): 330-43) the aim was to contribute to the endeavour of further globalizing the discipline. In International Relations Theory: A New Introduction (Knud Erik Jorgensen, International Relations Theory: A New Introduction (Basingstoke: Palgrave Macmillan, 2017)), I included a chapter on DIY theorizing, hoping it would give students (and perhaps their professors) the tools, building blocks and courage to engage in building their own theories. Finally, "After Hegemony in International Relations" (Knud Erik Jorgensen, "After Hegemony in International Relations," European Review of International Studies 1, no. 1 (2014): 57-64) while celebrating the arrival of the European Review of International Studies included an attempt to induce an ethics of responsibility for developing the disciplinary features that can be said to be weakly developed in major parts of the global IR community. 


\section{The Value of Theoretical Knowledge}

The beach at the small Cornish town Porthcurno appears as just a beach but it is not. The beach is where the sea communication cables from many corners of the British empire entered Great Britain before continuing to London, the metropole and epicentre of the empire. The beach at Porthcurno - triggering powerful connotations of empire, hierarchy, hegemony as well as centre and periphery - is a suitable image of how various critics present past and contemporary acts of theorizing within the IR discipline. They claim that theorists within the dominant power(s) theorize global affairs by means of a local language, typically English. They also claim that the knowledge that in abstract or synthesized form constitute their theories is universal and that their theories are universally applicable. In the rest of the world there are no theorists and no IR theory is being produced, indeed knowledge in the form of theory is not appreciated or cherished. Calls to globalize the discipline and its theories are meant to change this state of affairs and different approaches are employed. Some point to parochialism masquerading as universalism. Others suggest that the discipline should be dismantled. ${ }^{4}$ Still others point to the fact that the world is bigger than the main centres of theorizing. I tend to follow the latter avenue arguing that the Porthcurno image is misleading, and for two reasons. The dichotomies of the British Empire/the rest or 'the West/the rest' make more harm than good and obscures the distribution of agency in the field of theory building. Moreover, theorizing is cherished throughout the world. In other words, thinking theoretically is not exclusively a feature of 'the West' and anti-theoretical sentiments are not exclusively a feature of the non-West.

The following triptych of questions is crucially important for understanding both the universal yet contested value of theory and the potential value of the 100 workshops:

- What is theory?

- What is the theorizing process?

- What is the value of theoretical knowledge?

Given that defining theory is a task in itself, I have to be pragmatic so the following definition therefore works for me. According to Kenneth Waltz, "Theory is artifice. A theory is an intellectual construction by which we select facts and interpret them. The challenge is to bring theory to bear on facts in ways that permit explanation and prediction. That can only be accomplished by distinguishing between theory and fact. Only if this distinction is made can theory be used to examine and interpret facts". ${ }^{5}$ It is the feature of artifice and the distinction between theory and fact that I in the present context find useful for understanding the nature of theory. I would add, though, that there are different kinds of theory: explanatory, interpretive and normative and, each kind has its own distinct features. ${ }^{6}$

The theorizing process is a strangely under-described activity. ${ }^{7}$ It is as if theorists, like magicians, do not want to reveal theory secrets and others do not dare to explore. Donald Puchala is an exception, suggesting that theorists do the following when they theorize,

\footnotetext{
4 Chris Brown, Practical Judgement in International Political Theory: Selected Essays (Abingdon: Routledge, 2010).

Kenneth N. Waltz, "Realist Thought and Neorealist Theory," Journal of International Affairs 44, no. 1 (1990): 22.

Scholars who are not used to think theoretically often spend considerable time either on approximating theory to facts (1:1 being the most extreme case and the most useless) or, concerned about the prevalence of contending theoretical perspectives, on erasing contention in an attempt to build a monistic theory construction.

I call it 'strangely under-described' because on the one hand theories are cherished as the backbone of the discipline but, on the other hand, most theorists do not describe what they do when they build theories. By contrast, the procedures for application of theory are described in an abundance of textbooks on methodology.
} 
"[t]he theorists are first and foremost conceptualizers, symbolizers, synthesizers, and abstract organizers ... what they have been doing as theorists is painting for us in their writings boldstroked, broad-brushed pictures of social reality and telling us that the real world is their pictures." 8

We now have an idea about what the theorists at the workshops are supposed to produce and the key characteristics of the production process. But why is what they do valuable? What's the value of theoretical knowledge? The short version of the story about the value of theory is, in the words of Stanley Hoffmann and Robert Keohane, that 'attempts to avoid theory not only miss interesting questions but rely implicitly on a framework for analysis that remains unexamined precisely because it is implicit'. ' I share Keohane and Hoffmann's take on the role of theory and believe it has profound ramifications for our global discipline that the production of theoretical knowledge is uneven and that frameworks for analysis are left unexamined. It is high time to critically examine the unexamined frameworks no matter whether they originate in the North, South, East or West. I should like to add that theory has a number of different roles: guiding empirical research, inspiring research agendas, providing a scientific alternative to ideology and conspiracy theory. It is telling that geopolitics thrives as a framework for understanding world politics especially in areas where the IR discipline is less established. ${ }^{10}$

Hence, on the pro side we will not miss interesting questions and we will get a chance to examine implicit assumptions. Such values are cherished in certain segments of the scholarly community but importantly, they are not shared throughout the community. Empiricists just want the descriptive or analytical job done without much theoretical fanfare and methodologists consider theories to be, at best a reservoir of hypotheses. ${ }^{11}$ It seems to me that Mearsheimer and Walt are spot on with their criticism of an approach that is trending especially within international studies as cultivated in the United States. Some naively consider paradigmatic theories, the so-called 'isms', to be downright 'evil'. ${ }^{12}$ Others consider metatheory to be even worse, ${ }^{13}$ a position that unfortunately suggest an unwarranted abandonment of an entire scholarly field of enquiry. ${ }^{14}$ The above examples are all 'Western' deliberately selected to show that it is not the case that theoretical knowledge is cherished in 'the West' but not in the 'South' or 'East'. It seems that the balance of power between explicit and implicit theoretical knowledge varies around the world. What matters might be the degree to which universities are autonomous vis-à-vis political-ideological or religious institutions. At the individual level those in the policy or media worlds who make careers on the basis of 'knowing about international affairs' do typically not see the value of making

Donald J. Puchala, Theory and History in International Relations (London: Routledge, 2003), 24.

9 Robert O. Keohane and Stanley Hoffmann, "Conclusions: Community Politics and Institutional Change," in The Dynamics of European Integration, ed. William Wallace (London; New York: Pinter Publishers for the Royal Institute of International Affairs, 1990), 284.

10 Stefano Guzzini, The Return of Geopolitics in Europe? Social Mechanisms and Foreign Policy Identity Crises (New York: Cambridge University Press, 2012).

11 Mearsheimer and Walt, "Leaving Theory Behind".

12 David A. Lake, "Why "isms" are Evil: Theory, epistemology, and academic sects as impediments to understanding and progress," International Studies Quarterly 55, no. 2 (2011): 465-80. For an eminent critique see, Henry R. Nau, "No Alternative to 'isms'," International Studies Quarterly 55, no. 2 (2011): 487-91.

13 Andrew Moravcsik, "Is Something Rotten in the State of Denmark? Constructivism and European Integration," Journal of European Public Policy 6, no. 4 (1999): 669-81; Joseph Jupille, James A. Caporaso, and Jeffrey T. Checkel, "Integrating Institutions Rationalism, Constructivism, and the Study of the European Union," Comparative Political Studies 36, no. 1-2 (2003): 7-40.

14 While Andrew Moravcik criticized metatheory in one article, he engaged at the same time in metatheoretical analysis in another article. See, Moravcsik, "Is Something Rotten in the State of Denmark?"; Jeffrey W. Legro and Andrew Moravcsik, "Is anybody still a realist?" International Security 24, no. 2 (1999): 5-55. 
implicit assumptions explicit and, even worse, to have their implicit assumptions examined. The advancement of IR theory would then potentially alter the balance of power between IR scholars who believe in science and those who rely on alternative frameworks or political or religious authorities. Theorists at the workshops should be fully aware of such institutional or individual power relations.

\section{Market Analysis}

The second section provides a brief market analysis and thus focuses on supply and demand or producers, the retail sector and consumers. If 100 workshops were to make a difference, what exactly would the difference be? Let us assume that the 100 workshops actually take place and that many of the participants succeed in building both paradigmatic and mid-range theories as well as both first and second order theory. ${ }^{15}$ The 100 workshops would in terms of output be a great success but what about outcome. Would they change anything? The supply of theories would be significantly increased but what about the demand? My hunch is that not that much would be different and three reasons explain why.

First, the newly built theories would not necessarily be part of the 'consensual foundational' literature ${ }^{16}$ but instead face an existence at the fringe of the discipline. In other words, their reception might not be as the authors intended or as the theories would deserve. The dialectics of author intent and reception is often unpredictable and some of the new theories might be capable of creating their own demand.

Second, following the Hollywood/Bollywood analogy we can critically ask if the new theories would be Bollywood productions. Bollywood movies entertain millions of people so perhaps the world market should not be the only indicator of success. In turn, we can therefore ask if such an outcome necessarily would be so bad. Do the new theories necessarily need to conquer the world market? The twins of modernization theory and dependencia theory can serve as illustrative examples of limited reach yet nonetheless some impact. By contrast, if the theorists do aim at the world market, then what would it take to enter and become established in the world market? A third option is Pinewood, a film studio that is especially known for its signature James Bond movies, and thus representing a distinct tradition of its own. The various theoretical schools around the world - for instance Amsterdam, Copenhagen, Toronto, Stanford - could perhaps be seen as Pinewood productions. No laws of nature suggest that theoretical schools cannot emerge in Shanghai, Izmir or Cape Town.

Third, authors do not always control the reception of their theories. To do so takes extraordinary efforts, some luck and persistence. ${ }^{17}$ The first hurdle is the mandatory peer assessment of quality and relevance. While the quality of theories is essentially contested, a genuine take-off requires recognition by a considerable segment of the market. Somehow theories produced in the traditional centre of knowledge production tend to be cherished more than theories built elsewhere, so an uphill battle is predictable. It is presumably the celebrity factor at play (celebrities are people who are known to be known). The second hurdle is socialization within the discipline of new generations of scholars. Hence the new theories need to be included in textbooks and be part of $\mathrm{PhD}$ training programmes. It will take some

15 For a concise distinction, see Alexander Wendt, "Constructing International Politics," International Security 20, no. 1 (1995): 71-81.

16 cf. section five below.

17 Hans Morgenthau submitted the manuscript published as Politics among Nations to 13 different publishers before New Yorkbased Simon and Schuster finally accepted it. 
effort to persuade authors of textbooks and $\mathrm{PhD}$ programme planners to include the new theories. The cases of the English School and world systems theory illustrate the challenge as they struggle to become part of what is taught. The third hurdle is time. Theoretical dynamics tend to be characterized more by a certain slowness and inertia than rupture and quick adaptation. It took a decade, the 1990s, to cut the realist theoretical tradition to size and a similar amount of time to consolidate constructivist advances. Moreover, if textbooks were compared across time, it is clearly the case that their profile changes. Textbooks of the 1970s are very different from textbooks in 2017. Finally, while it takes considerable time to criticize existing textbooks for all their flaws, it will take considerably longer time for the critics to write the perfect textbooks they demand.

In summary, Leca's distinction between academic domestic and global markets makes sense and can serve as a useful starting point for theorists when considering their ambitions. ${ }^{18}$ Is the aim of theory building to serve a number of domestic or regional markets or is the aim to be of consequence at the world market. In order to secure the desired outcome the three factors mentioned above need to be handled.

\section{Global Pluralism is a Fact (Get Used to It!)}

The aim of home-grown theorizing outside the traditional centres is sometimes to change what is described as theoretical hegemony within the discipline. However, if at some point European or American hegemony characterized the discipline, it no longer does. A degree of European hegemony characterized the main institution for the advancement of the discipline before WW2, i.e. the International Studies Conference (ISC) but the ISC was 'killed' in 1950. ${ }^{19}$ Subsequently the discipline became more institutionalized in the United States than elsewhere and the 1959 ISA secession from APSA is in this context a not insignificant factor. This paper takes the position that contemporary hegemony is very limited for which reason the often limited state of home grown theorizing outside traditional centres should not be explained primarily by means of external factors. The proposed 100 workshops represent simply one way of taking responsibility for changing the current state of affairs and in turn engage in upgrading the level of theorizing outside the current sites of production. In short, we are now in an after hegemony situation and this enables a range of opportunities but also presents several challenges.

The first opportunity to change the theoretical set-up of the discipline is based on the fact that most major cities around the world enjoy a critical mass of IR scholars with an interest in theoretical issues. They can organize workshops or symposia that focus on the different ways of engaging in theory building. The organization of such workshops is not dependent on a green light from a faraway hegemon. In contrast to workshops on big $\mathrm{n}$ dataset research, theory workshops do not require investments in expensive research infrastructure. The workshops merely require time and space to 'think theory thoroughly' plus perhaps some personal predispositions, to paraphrase Rosenau and Durfee. ${ }^{20}$

\footnotetext{
18 Leca, "La science politique".

19 David Long, "Who Killed the International Studies Conference?" Review of International Studies 32, no. 4 (2006): 603-22.

20 James N. Rosenau and Mary Durfee, Thinking Theory Thoroughly: Coherent Approaches to an Incoherent World (Boulder, CO.: Lynne Rienner, 1995). In Thinking Theory Thoroughly, Mary Durfee and James Rosenau present a comprehensive account of what it takes to think theoretically, at least concerning causal empirical theory. In terms of thoroughly examining the nature of the theorizing process the book is simply unique.
} 
The second opportunity is caused by the fact that theorizing does not necessarily need to begin from scratch, for instance by means of developing an entirely new vocabulary. The behavioralists of the 1960s opted for this kind of approach yet the results did not exactly live up to expectations. The process of theory building can begin with more modest objectives, for instance conceptualization, reconceptualization, theory synthesis or projects of reconstruction. If our collective objective is to understand global politics and economics then we need to translate our demand for knowledge into a number of research questions or research agendas. Such questions or agendas are not necessarily global or universal but can hardly avoid being influenced by our distinct centric perspectives. We engage in theoretical thinking because we believe it can help us achieve our general objective and help us transcend our centrism of various kinds. Both theory building and theory application have instrumental functions and are not ends as such. When we engage in conceptualization we do it because we have distinct research questions and agendas in our mind. When we engage in re-conceptualization we do so because we think existing concepts are inadequate vis-à-vis our questions and agendas. Likewise we engage in theory synthesis and theoretical reconstruction because the outcome provides a better match to our questions or a better guide to our analysis, i.e. the process through which we aim at finding answers to our questions.

Third, theory builders could perhaps find inspiration in the approach adopted by a group of Danish film directors, Dogme 95, consisting of a number of self-imposed limits, the purpose being enhanced creativity in areas that are unlimited. In the case of movie directors, they decided to only use natural lighting. In the case of theory builders I will for purely illustrative purposes mention two options: perhaps 50 workshops could focus entirely on building structural theories and 50 workshops could focus on agent-oriented theory building. Yet it would be for the workshop organizers to decide the constraints that would be imposed on the theorists. In any case, whereas homegrown theorizing is bound to begin at home it can end with a theory of home or a universal theory. Realist balance of power theory is the outcome of theorizing $19^{\text {th }}$ century power politics in Europe (home) yet it might nonetheless have universal characteristics and thus be applicable elsewhere, for instance in studies of the Middle East, Africa or eastern Asia. Likewise, some theoretical traditions within Japanese IR contain homegrown theories, thus originating in Japan but the theories might be applicable elsewhere. Dependencia theory mainly took off in Latin America yet also found an audience on other continents.

Fourth, the production of many new first order theories carries the opportunity to strengthen the discipline of IR. After decades of endeavours to destabilize the discipline, for which reason the discipline remains contested, it would be most helpful for both the theories and the discipline if the new theories were built within the framework of the discipline and thus contribute to develop the discipline rather than dismantle it.

Fifth, while the 100 workshops can be and should be seen as an example of the 'let 100 flowers blossom' doctrine, the workshops/panels would unquestionable have more impact if connected to or organized within major existing associations, including WISC, the ISA, and EISA. It does not take too much effort to organize workshops, symposia, sections or panels. In addition to the venues of the major associations, financial constraints suggest that smaller events would be necessary, not least because the workshops should be global and despite aspirations, the major association events do not have complete global reach. 
All these opportunities are to some extent available and are indeed in the process of being exploited, i.e. contemporary workshops do generate new theories. The existence of a dozen theory building projects indicates that the interest in theorizing is on the rise. ${ }^{21}$ Actually, one of the biggest challenges is to remain up to date on the many projects and thus realize the high degree to which the contemporary discipline is characterized by pluralism.

\section{Theorizing the Local and the Bygone?}

Globalizing the discipline implies changing the discipline and change depends on criticism. The 100 workshops should therefore be characterized by profound criticism, aimed at changing the profile of the discipline. However, in order to build theories, criticism should not be limited to critique. It should be an instrumental starting point, i.e. function as a platform for building theories. One example is E.H. Carr's Twenty Years Crisis which is partly a critique of currents within the liberal tradition but also an example of early $20^{\text {th }}$ century realist thought. Moreover, criticism should have a genuinely global perspective and theorizing should be relevant for the $21^{\text {st }}$ century. Genuinely global perspectives do obviously not equal Global South perspectives but should be inclusive of all perspectives. In this context Kimberly Hutchings seems to believe that her best contribution to a globalized IR is to be increasingly quiet thereby leaving space to non-Western perspective. ${ }^{22}$ It seems to me that engagement is a better option.

Unfortunately, current critique is far from being global and, moreover, tends to focus on a bygone world. Criticism of the discipline and its theories is frequently characterized by conventions and a certain degree of orthodoxy. Thus, critique of Eurocentrism is conventionally a critique of Western, i.e. European or American instances of adopting centrist perspectives. However, Eurocentrism is only one distinct centric perspective and globally, centric perspective are widespread if not ubiquitous. Likewise, studies of empire are conventionally characterized by a more or less relevant critique of European or American imperial practices, ${ }^{23}$ yet strangely overlook the role of empire in contemporary Russian, Chinese or Iranian (foreign policy) discourses. ${ }^{24}$ Studies and critique of racism in the discipline conventionally focus on Western racism yet racism seems to be a global phenomenon and should in the context of globalizing IR be analysed as such. ${ }^{25}$ Finally, studies and critique of

${ }^{21}$ The projects include, Emilian Kavalski et al, "Encounters with the Post-Western World Affairs of Eastphalia" (preliminary publication title); Ingo Peters and Wiebke Wemheuer-Vogelaar, eds., Globalizing International Relations (London: Palgrave, 2016); Pinar Bilgin, "How to Remedy Eurocentrism in IR? A Complement and a Challenge for The Global Transformation," International Theory 8, no. 3 (2016): 492-501; Amitav Acharya's project on "An IR for the Global South or a Global IR?" E-IR, October 21, 2015, accessed August 28, 2016, http://www.e-ir.info/2015/10/21/an-ir-for-the-global-south-or-aglobal-ir/; Imad Mansour, "A Global South Perspective on International Relations Theory," International Studies Perspectives 18 (2016): 2-3 doi: https://doi.org/10.1093/isp/ekw010; Audrey Alejandro, et al., Reappraising European IR Theoretical Traditions (London: Palgrave, 2017).

22 Kimberly Hutchings, "Kimberly Hutchings on Quiet as a Research Strategy, the Essence of Critique, and the Narcissism of Minor Differences," by A.S. Bang Lindegaard and P. Schouten, Theory Talks, October 10, 2016, accessed November 10, 2016, http:// www.theory-talks.org/2016/10/theory-talk-73-kimberly-hutchings.html.

${ }_{23}$ Edward Keene, Beyond the Anarchical Society: Grotius, Colonialism and Order in World Politics (Cambridge: Cambridge University Press, 2002); Hartmut Behr, "The European Union in the Legacies of Imperial Rule? EU Accession Politics Viewed From a Historical Comparative Perspective," European Journal of International Relations 13, no. 2 (2007): 239-62; see also David A. Lake, "The New American Empire?" International Studies Perspectives 9, no. 3 (2008): 281-9.

${ }^{24}$ Henry R. Nau and Deepa M. Ollapally, eds. Worldviews of Aspiring Powers: Domestic Foreign Policy Debates in China, India, Iran, Japan, and Russia (Oxford: Oxford University Press, 2012); Dmitri Trenin, Post-Imperium: A Eurasian Story (Washington DC.: Carnegie, 2011); Marcel H. van Herpen, Putin's Wars: The Rise of Russia's New Imperialism (Lanham: Rowman and Littlefield, 2014).

${ }^{25}$ In his APSA Presidential address, Peter Katzenstein addressed the issue of racism in political science. See, Peter J. Katzenstein, “'Walls' Between 'Those People'? Contrasting Perspectives on World Politics," Perspectives on Politics 8, no. 1 (2010): 
orientalism conventionally focus on European or American instances of orientalist practices. But orientalism is merely a concept within the wider category of mis-representations (taking images for true representations of the other), an exercise in which Europe hardly can claim monopoly. It would be a pity if the theorists at the 100 workshops continue the present current of critical approaches turned orthodox.

The frequently employed dichotomy of 'the West' and 'the non-West' appears to be foremost an important obstacle to globalizing the discipline, yet is often presented as part of a solution to a claimed problem. The distinction clearly exaggerates similarities within and differences between the categories and thus obscures the fact that major parts of Europe can be characterized in ways that are strikingly similar to how 'the non-West' tends to be characterized. Jacek Czaputowicz and Anna Woyciuk identify features of Polish IR that Siddharth Mallavarapu claims characterize Indian IR. ${ }^{26}$ Furthermore, what exactly is "the West'? While it might include traditions within Japanese IR that were imported (from Germany) what about the home-grown IR traditions in Japan? Finally, what to do about theorists on the move, for instance the Australians Coral Bell, John Burton and Hedley Bull who all contributed to International Relations in Europe. Does South African Charles Manning's theory of international society count as 'Western' or 'non-Western IR'? Do we, when applying the theory of orientalism, ${ }^{27}$ apply a Western (Columbia University, NYC) or non-Western theory (built by a Palestinian, and therefore south, east, north or west)?

Theorists face not only a certain degree of orthodoxy in current critical approaches but also the inclusion of non-Western theoretical perspectives, an inclusion which is not without its problems. The employment of distinctly non-western concepts is obviously a notable challenge to lazy Western minds and a highly disquieting factor in the (de-)construction of our worldviews and globalizing discipline. Increased employment of notions like ubuntu or tianxia (and many more) would obviously extend the discipline's vocabulary and might thus contribute to de-centralize the discipline. ${ }^{28}$ Yet it is an even bigger cognitive challenge to acknowledge that non-Western theoretical reflections frequently are primed by features that critical IR aims at problematizing. ${ }^{29}$ The following three challenges for a sound six continents IR discipline therefore amount to a mission nearly impossible.

First, exceptionalism is not particularly exceptional but characterizes ways of thinking around the world. While the American and European versions are exceptionally well-known and occasionally assumed to be exceptional in the world, scholarship on Russia, India and China suggest otherwise indeed demonstrates the significance of exceptionalism with Russian, Indian or Chinese characteristics. ${ }^{30}$ Actually, exceptionalist thinking is so widespread that it

11-25. Robert Vitalis has provided the probably most comprehensive account of racism in American International Relations. See, Robert Vitalis, White World Order, Black Power Politics: The Birth of American International Relations (Ithaca: Cornell University Press, 2015). At some point students in Ghana protested against a new statue of Mahatma Ghandi, claiming he had racist attitudes towards Africans for which reason they requested the statue removed. See, "'Racist' Gandhi statue banished from Ghana university campus," Guardian, October 6, 2016, accessed November 10, 2016, https:/www.theguardian.com/world/2016/oct/06/ghanaacademics-petition-removal-mahatma-gandhi-statue-african-heroes.

26 Jacek Czaputowicz and Anna Wojciuk, The Study of International Relations in Poland (Basingstoke, UK: Palgrave Macmillan, 2017); Siddharth Mallavarapu, "Development of International Relations Theory in India: Traditions, Contemporary Perspectives and Trajectories," International Studies 46, no. 1-2 (2009): 165-83.

27 Edward W. Said, Orientalism (New York: Pantheon Books, 1978).

28 Karen Smith, "Reshaping International Relations: Theoretical Innovations from Africa," All Azimuth 7, no. 2 (2018): 81-92.

29 For an early critique, see William A. Callahan, "China and the Globalisation of IR Theory: Discussion of 'Building International Relations Theory with Chinese Characteristics'," Journal of Contemporary China 10, no. 26 (2001): $75-88$.

${ }^{30}$ Andrei P. Tsygankov, "Self and Other in International Relations Theory: Learning from Russian Civilizational 
somewhat hard to find exceptions to this very special local yet seemingly universal way of thinking. Moreover, ethnocentrism is as widespread as exceptionalism and both documented and in some cases represented by scholarship. Finally, theorists in the West do not enjoy a monopoly in the market of universal ideas. Similar to western liberalism, Confucianism is universalistic, cf. notions like tianxia and expectations about a global order with Chinese characteristics, beginning with China's (peaceful?) rise.

In a truly global six continents IR discipline it will be difficult but not impossible to acknowledge that Europe (or the West) does not enjoy a monopoly of exceptionalism, ethnocentrism and universalism, for which reason criticism of European or Western versions remain relevant but should be extended to generic ways of thinking and subsequently extended to local versions.

\section{Towards a Consensually Foundational Literature}

Theorists in the 100 workshops should aim at contributing to what Ted Hopf calls, "a particular well-known consensually foundational literature". ${ }^{31}$ In other words, the target should be the core of the discipline. Otherwise the theories might experience a life at the fringes of the discipline, an existence that some might deem satisfactory but, again, if the general aim is to globalize the discipline then it is necessary to aim higher.

However, aiming at a consensually foundational literature is highly controversial, not least because it implies disciplinary features such as boundaries, foundations, trajectories, traditions, inclusions and exclusions as well as processes of deliberation that are capable of producing a new consensual foundational literature. In other words, if it really is 'the discipline' (and its theories) we aim at globalizing then conceptualizing disciplinary identity is a (pre-)condition for achieving the objective. Unfortunately pleas to globalize the discipline are frequently made without much reflection about the nature of the discipline or its uneven development and different trajectories in different parts of the world.

Tracing the trajectories takes some effort and is complicated by the fact that the nature of the discipline seems foremost to be a synthesizing or fusion discipline, this in contrast to most other disciplines that are the result of fission or splintering, e.g. molecular biology splintering off from biology yet preserves affiliations with biology. The suggestion that new theories should contribute to a consensual foundational literature is meant to counter loose non-committing references to 'the discipline' or, even more vague, 'IR'.

The good news is that the consensual foundational literature is not etched in stone but somewhat dynamic as figure 1 illustrates.

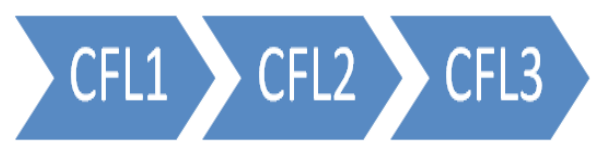

Figure 1: Variations of 'Consensually Foundational Literature' (CFL) over time

Debates," International Studies Review 10, no. 4 (2008):762-75; Alexander Dugin, "Theory Talk \#66: Alexander Dugin on Eurasianism, the Geopolitics of Land and Sea, and a Russian Theory of Multipolarity," by M. Millerman, Theory Talks, December 7, 2014, accessed August 2, 2016, http://www.theory-talks.org/2014/12/theory-talk-66.html; Priya Chacko, Indian Foreign Policy: The Politics of Postcolonial Identity from 1947 to 2004 (Oxon: Routledge, 2013); Deepa M. Ollapally and Rajesh Rajagopalan, "India: Foreign Policy Perspectives of an Ambiguous Power," in Nau and Ollapally, Worldviews of Aspiring Powers, 73-113; Lucian W. Pye, The Spirit of Chinese Politics (Cambridge, MA: Harvard University Press, 1992). 
The issue of a consensual foundational literature can be approached at both macro and micro levels. At the micro level we have the individual theorist who almost necessarily will build a given theory in the context of the macro level, i.e. the institutional, disciplinary settings. It would thus probably be insufficient to just assemble the building blocks of theory in new creative fashions, even if such theorizing would be for someone or for some purpose.

At the macro (institutional) level discipline requires a foundational literature, e.g. a canon of 50, 100 or 225 foundational publications. However, what exactly does 'consensual' mean? Unless globalizing equals a process through which the existing foundational literature is taken on as is, the globalizing process implies redefining the foundational literature. It is a body of literature that is not etched in stone but changes over time. Thus, the foundational literature of the 1950s is different from how it looks nowadays. Moreover, it is an essentially contested body of literature left in the hands of individual scholars or departments who design courses and syllabi as in their judgement it would be the best way to teach students. Fortunately, such designs are in many places not in the hands of government or association regulatory committees but left to individual scholars or university departments. The general aim for the workshops is to reshape the core canon of the discipline, yet such a thorough reshaping would be a gradual and long lasting process, a continuation of an already ongoing process. It is predictable that the outcome of the 100 workshops would be a significant body of new concepts and theories, some of which would be sufficiently compelling to be adopted in syllabi and enter into the list of standard references. The process can be illustrated by the concept 'securitization'. It started as a one-man idea ${ }^{32} 25$ years ago yet has generated a sizeable literature and entered numerous syllabi around the world and thus become part of a redefined foundational literature.

How do scholars think the social reality of foundational literature should be changed? I will briefly examine five scholarly approaches.

First, according to Meera Sabaratnam, the preferred approach is to 'throw away' conceptions or 'putting down' unwarranted literature,

\footnotetext{
"Such openings are made eminently possible-indeed necessary - by Hobson's comprehensive critique of Eurocentrism in world politics. I would also like to say that this should also mark the opportunity also to start putting down many of the Eurocentric texts that have populated reading lists for so long, and in doing so re-make the discipline more fit for purpose - a truly inclusive account of global interactions and politics, told from many sides, alert to multiple layers of connectivity, relationality and resonance as well as violence, dispossession and conflict. Hobson's excellent book highlights again just how short-sighted and parochial Eurocentric conceptions of world politics have made us. The question is, now we have recognised this, do we have the courage, imagination and ability to throw them away?" ${ }_{33}$
}

Sabaratnam's approach might be innocent and fully in line with how disciplinary practices have been for decades. For all sorts of reasons individuals or departments decide frequently to drop a text from a syllabus and replace it with a different text. This is one of the ways in which the English School has experienced a renaissance, simply by means of being increasingly recognized as a part of the foundational literature. Sabaratnam declares she wants to avoid

32 Ole Wæver, "Securitization and Desecuritization," in On Security, ed. Ronnie Lipschutz (New York: Columbia University Press, 1995), 46-86.

33 Meera Sabaratnam, “The Citadel Has Been Blown Up. Hurray! Next? A Response to Hobson," The Disorder of Things (blog), September 24, 2012, accessed on September 12, 2016, https://thedisorderofthings.com/2012/09/24/the-citadel-has-beenblown-up-hurray-next-a-response-to-hobson/. 
being 'short-sighted and parochial' yet it is unclear if she considers Eurocentrism to be the only obstacle to achieve the objective. Moreover, it seems to me that the characteristics of a 'discipline more fit for purpose' are accurate descriptions of the discipline that already exists.

Second, in "Permeability of Disciplinary Boundaries in the Age of Globalization: Interdisciplinary Scholarship in International Relations," Ehsanul Haque finds interdisciplinarity a promising approach, ${ }^{34}$

\begin{abstract}
"In a globalized world, we witness an entirely new, unprecedented form of knowledge production where the creation and utilization of knowledge is no longer seen as a linear process. In fact, the forces of globalization demand multiple disciplines to unravel and scientists transgress/cross disciplinary boundaries in their search for new knowledge creation and dissemination. Against this backdrop, this paper particularly reflects on the interdisciplinary character of International Relations (IR) - a successful and fascinating interdisciplinary subject having infinite boundaries. While IR is a full-blown, autonomous, and accomplished academic discipline, its hybrid curricula bring complementary strengths and enlarged perspectives from a diverse array of disciplines including Political Science, History, Economics, Sociology, Philosophy, and the like in order to address the everincreasing complexities and broader issues as well as to impart unified knowledge and produce cognitive advancement"... "students develop a 'meta-knowledge' of multiple disciplines, methods and epistemologies, and learn how to reflectively integrate and synthesize different perspectives. Finally, the paper concludes that such interdisciplinarity promotes quality research and contributes to solving new problems which cannot be addressed within the individual disciplines alone."
\end{abstract}

It is the idea of IR having hybrid features that ensures that it can be understood as both a discipline and an interdisciplinary field. However, it seems to me that hybridity can be taken too far. In other words, if IR at the same time is both subject and discipline, both discipline and interdisciplinary field then it might accurately describe the diverse ways in which IR is perceived but conceptual overstretch also kicks in and the diagnosis becomes unhelpful for guidance for the way forward for 'IR'.

Third, whereas I suggest new theories should be built within the framework of the discipline and thus contribute to develop the discipline rather than dismantle it, Chris Brown opts for a genuinely radical approach,

"If we truly wish to promote diversity in international thought, it may be that a crucial first step will be to contribute to the work of dismantling "International Relations" as an academic discipline". 35

This suggestion is in line with Brown's general dismissive stance concerning the disciplinary character of International Relations. ${ }^{36}$ In principle, Brown's approach could be compatible with my approach, especially if Brown by "International Relations" has an orthodox, set in stone perception of the discipline in mind. However, his criticism of Charles Manning's tireless work to consolidate the discipline can be seen as an indication that Brown is dismissive of any attempt to cultivate the discipline.

${ }^{34}$ Ehsanul Haque, "Permeability of Disciplinary Boundaries in the Age of Globalization: Interdisciplinary Scholarship in International Relations," (paper presented at the Conference of Academic Demarcations: Disciplines and Interdisciplinarity, University of Oslo, September 13-14, 2012).

35 Brown, Practical Judgement, 218.

36 See e.g., Brown, Practical Judgement. 
Fourth, Pierre Lizee suggest that the way forward is to reinvent the discipline, ${ }^{37}$

\begin{abstract}
"Engaging all these questions, though, means a step forward for the discipline, one that entails a re-examination of its basic language about what is universal and what is particular in international affairs. This is the last element in the reinvention of international studies proposed in this book"..."the key authors and texts which have shaped the nature and evolution of international studies as a discipline must be brought in when we consider these issues. To do otherwise would leave unresolved the one issue which must be addressed by international studies at the moment: the core canon of the discipline would remain unchanged, the "rise of the rest" would proceed apace, and the gap between the discipline and the world it now has to explain would grow, without ever being bridged. This is where, in the end, the most crucial challenge for international studies could lie at this time".
\end{abstract}

Lizee's approach has greatly inspired my own approach and his plea to reconsider the canon of the discipline might also be compatible with Sabaratnam and Haque. The approaches partly overlap, do include contending perspectives but are not mutually exclusive. The fifth approach adds to the fabric of reflections on the way forward.

Fifth, Audrey Alejando et al.'s Reappraising European IR Theoretical Traditions is based on the idea that wherever we are situated in the world, we should examine the trajectories of theoretical traditions. ${ }^{38}$ They are considered the backbone of the discipline for which reason it is highly worthwhile to know about their origins as well as how they have developed over time. The guiding idea for the project is that it is preferable, when setting sound future directions, that we know how we got to where we are. The authors of the book are all based in one geographical setting, Europe. When we reflect on world politics and economics, Europe provides our local coordinates. Our approach and findings, we claim, are valid for Europe but might/might not be applicable to or relevant elsewhere.

\title{
7. Conclusions
}

The 100 workshops on theory building could potentially make a significant difference and could have a most welcome impact on the process of globalizing the discipline of International Relations. In order to maximize the impact of home-grown theorizing, the value of theoretical knowledge needs to be spelled out in the rationale of the workshops and demonstrated in each of the theories built. Moreover, the paper takes the notion 'discipline' in 'globalizing the discipline' sufficiently serious to reject ideas of IR being a subset of any other discipline or merely an inter-disciplinary field. Instead it makes a plea to actually strengthen the discipline not least because it is only with a strong disciplinary core and an open mind that genuinely inter-disciplinary work can hope to be characterized by more analytical benefits than costs. Furthermore, theorizing should transcend orthodox critical approaches and while having a historical dimension it should not focus too much on bygone worlds. Instead theorizing should focus mainly on trends in the contemporary global order and its actors, structures and processes. Theories should aim at contributing to the so-called consensually foundational literature and thus potentially become part of the core of the discipline. It is highly likely that dispersed theorizing will have less impact but as theorizing is a creative and often

${ }^{37}$ Pierre Lizée, A Whole New World: Reinventing International Studies for the Post-Western World (Basingstoke: Palgrave, 2011).

38 Alejando, et al., Reappraising European IR; Audrey Alejando, "Eurocentrism, Ethnocentrism, and Misery of Position: International Relations in Europe - A problematic oversight," European Review of International Studies 4, no. 1 (2017): 5-20. 
individual enterprise it might be naïve or unwarranted to aim at über-concerted action. While philosophies and theoretical frameworks external to the discipline have proven to be immensely helpful for the production of insights about global affairs, it seems to me that the workshops primarily should focus on new first order substantial theories about international relations.

\section{Bibliography}

Alejando, Audrey. "Eurocentrism, Ethnocentrism, and Misery of Position: International Relations in Europe - A problematic oversight.” European Review of International Studies 4, no. 1 (2017): 5-20.

Alejando, Audrey, Knud Erik Jørgensen, Alexander Reichwein, Felix Rösch, and Helen Turton. Reappraising European IR Theoretical Traditions. London: Palgrave, 2017.

Behr, E. Hartmut. "The European Union in the Legacies of Imperial Rule? EU Accession Politics Viewed From A Historical Comparative Perspective.” European Journal of International Relations 13, no. 2 (2007): 239-62.

Bilgin, Pinar. "How to Remedy Eurocentrism in IR? A Complement and a Challenge for the Global Transformation." International Theory 8, no. 3 (2016): 492-501.

Brown, Chris. Practical Judgement in International Political Theory: Selected Essays. Abingdon: Routledge, 2010. Callahan, William A. "China and the Globalisation of IR Theory: Discussion of 'Building International Relations Theory with Chinese Characteristics'." Journal of Contemporary China 10, no. 26 (2001): 75-88.

Carr, E. H. The Twenty Years' Crisis, 1919-1939: An Introduction to the Study of International Relations. London: Palgrave, 1946.

Chacko, Priya. Indian Foreign Policy: The Politics of Postcolonial Identity from 1947 to 2004. Oxon: Routledge, 2013.

Czaputowicz, Jacek, and Anna Wojciuk. The Study of International Relations in Poland. Basingstoke, UK: Palgrave Macmillan, 2017.

Dugin, Alexander. "Theory Talk \#66: Alexander Dugin on Eurasianism, the Geopolitics of Land and Sea, and a Russian Theory of Multipolarity.” By M. Millerman. Theory Talks, December 7, 2014. Accessed August 2, 2016. http://www.theory-talks.org/2014/12/theory-talk-66.html.

Guzzini, Stefano. The Return of Geopolitics in Europe? Social Mechanisms and Foreign Policy Identity Crises. New York: Cambridge University Press, 2012.

Haque, Ehsanul. "Permeability of Disciplinary Boundaries in the Age of Globalization: Interdisciplinary Scholarship in International Relations.” Paper presented at the Conference of Academic Demarcations: Disciplines and Interdisciplinarity, University of Oslo, September 13-14, 2012.

Hobson, John M. The Eurocentric Conception of World Politics: Western International Theory, 1760-2010. Cambridge: Cambridge University Press, 2012.

Holsti, K.J. "Exceptionalism in American Foreign Policy: Is It Exceptional?" European Journal of International Relations 17, no. 3 (2010): 381-404.

Hopf, Ted. Social Construction of International Politics: Identities and Foreign Policies, Moscow, 1955 and 1999. Ithaca: Cornell University Press, 2002.

Hutchings, Kimberly. "Kimberly Hutchings on Quiet as a Research Strategy, the Essence of Critique, and the Narcissism of Minor Differences.” By A.S. Bang Lindegaard and P. Schouten, Theory Talks, October 10, 2016. Accessed November 10, 2016. http://www.theory-talks.org/2016/10/theory-talk-73-kimberly-hutchings.html. Jørgensen, Knud Erik. “After Hegemony in International Relations.” European Review of International Studies 1, no. 1 (2014): 57-64.

— . "Continental IR Theory: The Best Kept Secret.” European Journal of International Relations 6, no. 1 (2000): 9-42.

_ _ "Inter Alia: On Global Orders, Practices and Theory.” International Studies Review 9, no. 2 (2017): 283-87. 
. International Relations Theory: A New Introduction. Basingstoke: Palgrave Macmillan, 2017.

"Towards a Six Continents Social Science: International Relations." Journal of International Relations and Development 6, no. 4 (2004): 330-43.

Jørgensen, Knud Erik, and Reuben Wong. "Social Constructivist Perspectives on China-EU Relations.” In China, the European Union, and International Politics of Global Governance, edited by Jianwei Wang and Weiqing Song, 51-74. London: Palgrave, 2015.

Jupille, Joseph, James A. Caporaso, and Jeffrey T. Checkel. "Integrating Institutions Rationalism, Constructivism, and the Study of the European Union." Comparative Political Studies 36, no. 1-2 (2003): 7-40.

Katzenstein, Peter J. “'Walls' Between 'Those People’? Contrasting Perspectives on World Politics.” Perspectives on Politics 8, no. 1 (2010): 11-25.

Keene, Edward. Beyond the Anarchical Society: Grotius, Colonialism and Order In World Politics. Cambridge: Cambridge University Press, 2002.

Keohane, Robert O., and Stanley Hoffmann. "Conclusions: Community Politics and Institutional Change." In The Dynamics of European Integration, edited by William Wallace, 276-300. London; New York: Pinter Publishers for the Royal Institute of International Affairs, 1990.

Lake, David A. “The New American Empire?” International Studies Perspectives 9, no. 3 (2008): 281-9.

—. "Why "isms" are Evil: Theory, epistemology, and academic sects as impediments to understanding and progress.” International Studies Quarterly 55, no. 2 (2011): 465-80.

Langan, Mark. "Budget Support and Africa-European Union Relations: Free Market Reform and Neo-Colonialism?" European Journal of International Relations 21 (2015): 101-21.

Leca, Jean. "La science politique dans le champ intellectuel français." Revue française de science politique 4 (1982): 653-77.

Legro, Jeffrey W., and Andrew Moravcsik. “Is anybody still a realist?” International Security 24, no. 2 (1999): 5-55. Lizée, Pierre. A Whole New World: Reinventing International Studies for the Post-Western World. Basingstoke: Palgrave, 2011.

Long, David. "Who Killed the International Studies Conference?" Review of International Studies 32, no. 4 (2006): 603-22.

Mallavarapu, Siddharth. "Development of International Relations Theory in India: Traditions, Contemporary Perspectives and Trajectories." International Studies 46, no. 1-2 (2009): 165-83.

Mansour, Imad. “A Global South Perspective on International Relations Theory.” International Studies Perspectives 18 (2016): 2-3. doi: https://doi.org/10.1093/isp/ekw010.

Mearsheimer, John J., and Stephen M. Walt. "Leaving Theory Behind: Why Simplistic Hypothesis Testing Is Bad For International Relations.” European Journal of International Relations 19, no. 3 (2013): 427-57.

Moravcsik, Andrew. "Is something rotten in the state of Denmark? Constructivism and European integration." Journal of European Public Policy 6, no. 4 (1999): 669-81.

Nau, Henry R. “No Alternative to 'isms'.” International Studies Quarterly 55, no. 2 (2011): 487-91.

Nau, Henry R., and Deepa M. Ollapally, eds. Worldviews of Aspiring Powers: Domestic Foreign Policy Debates in China, India, Iran, Japan, and Russia. Oxford: Oxford University Press, 2012.

Ollapally, Deepa M., and Rajesh Rajagopalan. “India: Foreign Policy Perspectives of an Ambiguous Power.” In Nau and Ollapally, Worldviews of Aspiring Powers, 73-113.

Pan, Zhongqi. Conceptual Gaps in China-EU Relations: Global Governance, Human Rights and Strategic Partnerships. Basingstoke: Palgrave, 2012.

Peters, Ingo, and Wiebke Wemheuer-Vogelaar, eds. Globalizing International Relations. London: Palgrave, 2016.

Puchala, Donald J. Theory and History in International Relations. London: Routledge, 2003.

Pye, Lucian W. The Spirit of Chinese Politics. Cambridge, MA: Harvard University Press, 1992.

Qin, Yaqing. "Relationality and Processual Construction: Bringing Chinese Ideas into International Relations Theory.” Social Sciences in China 30, no. 4 (2009): 5-20. 
Qutb, Sayed. Milestones. New Delhi: Islamic Book Service, 2006.

Rosenau, James N., and Mary Durfee. Thinking Theory Thoroughly: Coherent Approaches to an Incoherent World. Boulder, CO.: Lynne Rienner, 1995.

Ruggie, John G. American Exceptionalism, Exemptionalism and Global Governance. KSG Working Paper No.

RWP04-006, Harvard University, February 2004. doi: http://dx.doi.org/10.2139/ssrn.517642.

_ . "Multilateralism: The Anatomy of an Institution." International Organization 46, no. 3 (1992): 561-98.

"Reconstituting the Global Public Domain-Issues, Actors, and Practices." European Journal of International Relations 10, no. 4 (2004): 499-531.

Said, Edward W. Orientalism. New York: Pantheon Books, 1978.

Scott, David A. "Multipolarity, Multilateralism and Beyond...? EU-China Understandings of the International System.” International Relations 27, no. 1 (2013): 30-51.

Shih, Chih, and Jiwu Yin. "Between Core National Interest and a Harmonious World: Reconciling Self Conceptions in Chinese Foreign Policy." The Chinese Journal of International Politics 6, no. 1 (2013): 59-84.

Shlapentokh, Dmitry. "Dugin's Eurasianism: A Window on The Minds of the Russian Elite or an Intellectual Ploy?" Studies in East European Thought 59, no. 3 (2007): 215-36.

Smith, Karen. "Reshaping International Relations: Theoretical Innovations from Africa." All Azimuth 7, no. 2 (2018): 81-92.

Trenin, Dmitri. Post-Imperium: A Eurasian Story. Washington DC.: Carnegie, 2011.

Tsygankov, Andrei P. "Self and Other in International Relations Theory: Learning from Russian Civilizational

Debates.” International Studies Review 10, no. 4 (2008):762-75.

van Herpen, Marcel H. Putin's Wars: The Rise of Russia's New Imperialism. Lanham: Rowman and Littlefield, 2014. Vitalis, Robert. White World Order, Black Power Politics: The Birth of American International Relations. Ithaca:

Cornell University Press, 2015.

Walt, Stephen. "International Relations: One World, Many Theories.” Foreign Policy 110 (1998): 29-46.

Waltz, Kenneth N. "Realist Thought and Neorealist Theory." Journal of International Affairs 44, no. 1 (1990): 2137.

Wang, Yiwei. "The Identity Dilemmas of EU Normative Power: Observations from Chinese Traditional Culture."

In Normative Power Europe in a Changing World: A Discussion, edited by A. Gerrits, 67-76. The Hague: The Netherlands Institute of International Relations, 2009.

Wæver, Ole. "Securitization and Desecuritization.” In On Security, edited by Ronnie Lipschutz, 46-86. New York: Columbia University Press, 1995.

Wendt, Alexander. “Constructing International Politics." International Security 20, no. 1 (1995): 71-81. 